prohibited; what the law on that point now is-upon all these and similar questions no opinion is intended to be expressed in the foregoing discussion. If injunctions are to be used, it seems clear to the present writer that the speedy review suggested must be provided for if we wish to preserve, perhaps one ought to say restore, the confidence of labor in the impartiality of our legal institutions.

W. W. C.

\title{
PRIVILEGE OF A LABOR UNION TO INDUCE A BREACH OF CONTRACT
}

Manufacturers of felt hats are divided into "makers" and "finishers," the former producing "hats in the rough" and the latter preparing them for the consumer ready to wear. In the recent case of $R$. \& W. Hat Shop Inc. v. Sculley (I922, Conn.) II8 Atl. 55, the plaintiff was a hat-finishing company running a non-union shop. The plaintiff had ordered a number of hats in the rough of one McLachlan, a hat "maker" running a union shop, and he had acccepted the order. A bilateral contract was thereby made, creating in each party a right to performance by the other with the correlative duty on each to perform. These "unital" rights and duties were the primary juristic effect of the operative acts of offer and acceptance; but, as a by-product of these operative acts, each contractor obtained innumerable (or "multital") rights in rem against all other individuals, each of whom bore a correlative duty not at all contractual in nature. These latter rights are often called, and were so called by the court in the instant case, a "property right in the contract." By virtue of the rule first laid down in Lumley $v$. Gye, the plaintiff had this "property right" against each third person, including the defendant Sculley, that such person should not, without just cause, induce McLachlan to break the contract to supply the plaintiff with hats in the rough.

Observe the term "without just cause." This phrase indicates that the plaintiff's right against Sculley was not absolute and unlimited. As soon as a "just cause" for Sculley's action exists, the plaintiff's right against Sculley ceases; and of course Sculley's correlative duty to forbear from inducing $\dot{M}$ cLachlan to break his contract likewise ceases. It is not accurate to say that the plaintiff has a right to noninterference unless the third person has an "equal or superior right." So far as appears in the case, Sculley (the third person in question) had no rights at all against McLachlan or the plaintiff and they owed no duty whatever to Sculley. The legal issue between plaintiff and Sculley was not between "rights," whether equal or superior to each

\footnotetext{
${ }^{1}$ (I853, Q. B.) 2 E1. \& B1. 216.

"This assumes that the plaintiff and the defendant can both have "rights," existing simultaneously side by side; and so indeed they can. The jural relations that are utterly inconsistent are right in the plaintiff to forbearance by the. defendant and privilege in the defendant not to forbear. These latter are the rclations in issue; and they are in issue because of an actual conflict in economic interests and desires.
} 
other. The issue was as follows: the plaintiff asserted that on the facts as they existed he had a right that Sculley should not induce McLachlan to break his contract with the plaintiff and that Sculley was under a duty to forbear from acting as he did; the defendant asserted that the plaintiff had no such right and that he had the legal privilege of acting as he did (that is, had no such duty to forbear). More briefly, the issue is right against no-right in the plaintiff; and duty against privilege in the defendant.

Sculley's action, concerning which this issue arose, and his reasons therefor, were as follows: In 1919, the hat business was booming. The makers of hats in the rough were not able to fill all orders of the hat finishers. The workmen in union hat-finishing shops were likely to be thrown out of work unless the makers of hats in the rough, of whom McLachlan was one, should supply union finishing shops in preference to non-union shops. Sculley was president of local No. ro, a union of "makers," being affiliated with the union of hat "finishers" in a large association called "United Hatters of North America." Acting at the instance of the national officers and solely for the purpose of keeping the affiliated union hat-finishers in work, Sculley went to McLachlan and made the following statement: "that in their judgment union 'finishing' shops should be given preference over non-union 'finishing' shops in the matter of supplying 'hats in the rough,' and that no shipments of these should be made to the latter until the needs of the union 'finishing' shops had been satisfied." The court finds that Sculley "knew or ought to have known," from statements made to him by McLachlan, that the latter had a contract with the plaintiff and that McLachlan would have to break this contract if he complied with Sculley's suggestion. The court further says: "Sculley used no threats to McLachlan, but he obeyed the instructions and breached his contract with plaintiff because of his knowledge of the power of the unions to embarrass him in the operation of his factory; and his fear that they would do so and exact a penalty from him. McLachlan would without these instructions have filled these orders, but he was not sorry to have a reason for breaching his contract with plaintiff, because he could obtain for the undelivered hats a price higher than the contract price."

From this we may assume, as does the court, that but for Sculley's act there would have been no breach of contract by 'McLachlan with the plaintiff. The court gave judgment for damages in favor of the plaintiff (Beach J., dissenting). In order to justify this decision, it is not sufficient to find that the defendant's act was one of the necessary antecedent facts in the absence of which McLachlan would not have broken his contract; the rapid rise in prices and McLachlan's own decision were also such facts. It must also be found that the defendant's act was "without just cause"-without any legally justifying reason that nullifies plaintiff's supposed "property right" against 
defendant and turns it into no right, that nullifies the defendant's duty to forbear to act and turns it into a privilege to act as he did.

The real problem before the court, therefore, was one of broad social policy. Did Sculley, on the existing facts, have "just cause"? Was the end to be attained so desirable that it counterbalances the injury inflicted? Is it for the general welfare that Sculley should have the privilege of acting as he did, or that Sculley should be forbidden by society and not have such privilege?

The findings of the court show that Sculley's purpose was the same as that actuating everybody else-success and survival in the struggle of life, in the competition for economic advantages. However, he did not expect that the direct result of his act would be money in his own pocket or in the pockets of the members of local No. Io, of which he was president. The expected direct result was to be a steady job for union hat-finishers, members of allied unions. Now it is generally agreed that success in life, a steady job, higher wages, are laudable objects for which to strive mightily in competition with other men. To be a laudable object the job does not have to be a job for oneself; it may be a job for one's son, business partner, or friend, or for someone closely allied in interest and social position. It is clear that Sculley had a laudable and permissible end in view. It appears also that he had no other purpose or end less laudable in character. He was not actuated by a desire to run amuck or by hatred and ill-will toward the plaintiff.

It needs no extended consideration to be convinced that a laudable purpose and a permissible end do not constitute "just cause" for every possible sort of action for attaining them. A highwayman does not have "just cause" for robbery and murder though his motive is to obtain food for his children. A defrauder does not have "just cause" for his lies. The fact that it may be more profitable to break a contract than to perform it does not constitute "just cause" for the breach. Law and organized government are maintained for the purpose of limiting freedom, of curtailing privileges, and of providing an orderly system of determining where privilege ceases and duty begins. The drawing of this line between privilege and duty is the chief function of courts; and it is no easy task, especially in cases of first impression. Interests and desires of classes, as well as of individuals, conflict with each other; and the line must be drawn by a nice balancing of interests and a compromise of desires. The rule applied must be one so consistent with general welfare and desire that it will receive the "common consent" or will otherwise receive the support of those who have the strength to control.

In the open competition of men for trade and business the limits of freedom are broad and the acts that are privileged are of many sorts; yet there are limits. Certain methods of trade and competition have been condemned and forbidden as "unfair." The privilege as against 
a competitor to use these "unfair" methods is denied, the duty not to use them created and enforced. It is usually lawful and privileged to undersell a competitor even though his business is ruined; a bidder is privileged to overbid his competitor and thus to prevent him from acquiring the goods he desires; a laborer is privileged to offer his services at a lower wage than that asked by others even though a competitor is caused to be without work. It does not follow, however, that these acts are privileged if their purpose and effect is to induce a breach of contract.

The doctrine of Lumley $v$. Gye declaring it to be tortious to induce a servant to break his contract with his master has been extended to all sorts of commercial contracts. ${ }^{3}$ The rule is not so broad, however, as to include all acts that cause a breach of contract. The motive with which the act is done is material." The majority opinion in the instant case reviews and quotes many previous opinions, and all alike use some limiting phrase. To procure a breach of contract, "maliciously," or "without just cause," or in "wanton disregard of the rights" of the plaintiff; is declared to be unlawful. They do indeed so define "maliciously" as not to require the element of hatred or ill-will $;$ but they make little effort to explain what it does require or to indicate what constitutes "just cause." As Sir Frederick Pollock has said, we do not need the House of Lords to tell us that a "wrongful" procurement of breach of contract is wrongful, or that an "unlawful"

\footnotetext{
${ }^{3}$ See (Ig2i) 3x Yale Law Journal, 2I2; Comments (Ig2i) 30 ibid. 618.

'In Aikens v. Wisconsin (1904) I95 U. S. I94, 204, 25 Sup. Ct. 3, 5, Mr. Justice Holmes says: "It has been considered that, prima facie the intentional infliction of temporal damage is a cause of action which, as a matter of substantive law, whatever may be the form of pleading, requires a justification if the defendant is to escape. Mogul Steanship Co. v. McGregor, [1892, H. L.] A. C. 25. If this is the correct mode of approach it is obvious that justifications may vary in extent according to the principle of policy upon which they are founded, and that while some.... are absolute,.... others may depend upon the end for which the act is done. Moran v. Dunphy (I90r) I77 Mass. 485, 59 N. E. 125. . . . It is no sufficient answer to this line of thought that motives are not actionable and that the standards of the law are external. That is true in determining what a man is bound to foresee, but not necessarily in determining the extent to which he can justify harm which he has foreseen. Quinn $v$. Leathem [IgoI, H. L.] A. C. 495, 524"" 2 Wigmore, Select Cases on the Law of Torts (I912) 890, says that malice as a test is "futile," but that "motive, however, must always be one of the considerations affecting the excuse."

${ }^{5}$ Lumley v. Gye, supra note I; Angle v. C. St. P., M. \& O. Ry. (I893) I5I U. S. I, I4 Sup. Ct. 240.

'South Wales Miners' Federation v. Glamorgan Coal Co. [Igas, H. L.] A. C. 239; Walker v. Cronin (I87I) I07 Mass. 555; Berry v. Donovan (I905) I88 Mass. 353, 74 N. E. 603 .

${ }^{7}$ Bitterman v. L. \& N. Ry. (Ig07) 207 U. S. 205, 223, 28 Sup. Ct. 9I, 97.

${ }^{8}$ Pollock, Torts (IIth ed. I920) 332; Bitterman v. L. \& $N$. Ry., supra note 7.
} 
act or an act "without lawful justification" is unlawful." In a few instances, one of which is the present case, the courts have said that economic competition is not justification. ${ }^{10}$ This comes reasonably near to a statement that no "just cause" for inducing a breach of contract can exist. Apparently no case, if we exclude strike and boycott cases, attempts to enlighten us on what constitutes a "just cause" for such a result.

Is assistance to be obtained from the cases involving strikes and boycotts? Beach J., dissenting, thinks there is. He says: "The question may be tested by inquiry whether the makers employed in his [McLachlan's] shop had a legal right [privilege] to strike in order to compel him to give priority in deliveries to union finishing shops." On the other hand, Wheeler, C. J., for the court, says: "The question of the right [privilege] of the makers in McLachlan's factory to strike is not involved in this case; nor is the question of their right to strike when they know that the strike will cause their employer to breach his contracts involved." It is true that Sculley does not appear to have been an employee of McLachlan and the court says that he "used no threats to McLachlan." But although the privilege of the workmen to strike is not being decided, it appears to be true that if they would be privileged to strike for the purposes involved in the action of Sculley, so too would their president Sculley be privileged to act for them in carrying on such a strike, and a fortiori in requesting McLachlan to bring about the desired end without threatening any strike at all.11 . The court is obviously loath to say that McLachlan's workmen would not be privileged to strike for higher wages for themselves in case they know that such a strike will make it impossible for him to perform his existing contracts with his customers. Should they not also, in spite of such contracts, be privileged to strike to prevent his using non-union materials or to prevent his sending his union-made materials to nonunion shops until all union shops are supplied? Judge Beach thinks that they are so privileged: "Although they knew of the contract, they might

- 'Pollock, op. cit. 330. "Epithets such as 'unlawful' prove nothing, but only beg the question." Isaacs, K. C., arguing in the Glamorgan case, supra note 6, at p. 243.

${ }^{10}$ Walker v. Cronin, stupra note 6. "Although he did it for the purpose of promoting his own business." In the instant case the court says that the defendant cannot justify his act by saying: "We did not do it to cause you injury or to breach your contract, but to improve our financial condition; the breach of your contract was a mere incident to the fulfillment of our purpose." See Angle v. Chicago etc., Ry., supra note 5; Beekman v. Marsters (Ig07) 195 Mass. 205, 80 N. E. 817; (I921) 31 YALE LAw Journal, 212.

"In South Wales Miners' Federation v. Glamorgan Coal Co., supra note 6, the workmen represented by the defendants were not so privileged. In that case their strike was itself a breach of contract with the plaintiff and this breach was directly ordered by the defendants. The causal connection was far more certainly proved and the establishment of "just cause" was far more difficult. 
strike for any reason for which they might lawfully strike in the absence of such a contract. Otherwise, employers of labor could extinguish the possibility of lawful strikes by, posting notices of their outstanding contract obligations." "12 This looks like a strong argument, both for justifying a strike and for justifying the defendant. If sound, it points directly to a line of decisions to which we can go for determining what is "just cause."13

Judge Beach is clearly correct when he says that "the duty to refrain from inducing one party to break his contract with the other is purely passive." It is a duty to forbear, not a duty to act. Neither McLachlan's workmen nor the defendant owed the plaintiff a duty to assist McLachlan to perform his contract with the plaintiff; and the latter surely had no right against them that they should actively assist. The majority opinion does not assert the contrary; but it definitely holds that the representatives of a union are under the legal duty not to make the "statement" made to McLachlan by the defendant when they know of his existing contracts inconsistent therewith. This is a "passive" duty, a duty to refrain from action. Whether or not the creation of such a duty is required by public policy and the general welfare is a question so near the border line that honest opinion may well differ. ${ }^{14}$

\footnotetext{
12 Observe that this argument is applicable only in cases where the strike is found to be the "proximate cause" of the employer's breach of contract. Is not the employer himself the "last wrong-doer" and the responsible cause of his own breach? The strike usually makes performance of contracts more difficult and expensive but not impossible. The employer can usually perform his contracts by yielding to the demands of the strikers. Conceivably, in the instant case, performance by McLachlan of his contract with the plaintiff was not made totally impossible by compliance with the defendant's suggestion; but such compliance by McLachlan made it necessary for him to see that all union "finishing" shops were supplied with hats in the rough before performing his contract with the plaintiff. How difficult this was may be inferred, but it was not shown in fact.

${ }^{13}$ The instant case bears a marked analogy to cases of strikes and secondary boycotts to prevent the use of non-union materials. The chief difference is that in those cases the defendant may have interfered only with the plaintiff's reasonable expectation of getting business and making profit, while in the instant case the breach of an existing contract is induced. Another difference is that in the former, union men strike against working with non-union materials; in the latter, the defendant was trying to prevent the working of union-made materials by non-union men until all union men were supplied. There is conflict as to the legal privilege of declaring secondary boycotts; a discussion of this cannot be attempted here. See a series of six comments entitled Present Day Labor Litigation (I92I) 30 Yale LAw Journal, 280, 404, 50r, 6I8, 736; (I921) 31 ibid. 86.

1s "In the last analysis the decision in a novel situation such as that presented in the principal case must turn upon notions of policy which the judges who are deciding the case may entertain." Cook, Privileges of Labor Unions in the Struggle for Life (I918) 27 YalE LAW JouRNAL, 779, 800. Writing on this and similar problems, Pollock says: "A wide field is left open to divergent views of economic and social policy." Pollock, op. cit. 336 .
} 
In arriving at a conclusion contrary to that of the majority of the court the present writer will very likely not be followed by the majority of lay or professional readers.

As one test of the defendant's duty to the plaintiff, let us try the shoe on the other foot. It will probably be admitted that a labor union and its president owe no greater "duty" to the plaintiff than do other men engaged in other lines of effort to make a living. Suppose that $\mathrm{X}$, the owner of a union hat-finishing shop, one who has been a constant purchaser of hats in the rough from McLachlan, one who has relied on him for a supply but who has no contract with him, should tell McLachlan that in his opinion McLachlan should in times of shortage supply his old customers first, and that if he does not do so he cannot expect their continued good will and trade. If McLachlan thereupon tells him that he has already contracted to supply the plaintiff first, must $\mathrm{X}$ acquiesce and inform McLachlan that his failure to supply $\mathrm{X}$ will have no evil consequences? Is not $\mathrm{X}$ instead privileged to leave the matter with McLachlan for decision and does not McLachlan bear the sole legal responsibility for his decision? Unquestionably, it is McLachlan's legal duty to the plaintiff to supply him in accordance with his contract, and for breach thereof the plaintiff has ample legal remedy against McLachlan. If McLachlan, because he fears a loss of future trade with $X$ (trade that $X$ is under no duty whatever to give him), chooses to break his contract with the plaintiff, is not the choice McLachlan's alone, and is not his act alone the proximate and the legal cause of the plaintiff's loss? It is believed that the court should hold in the affirmative, ${ }^{15}$. and that the decision should be the same whether the suggestion to McLachlan is

${ }^{15}$ This view was held in Parkinson Co. v. Building Trades Conncil (Ig08) I54 Calif. 58I, 602, $98 \mathrm{Pac}$. I027, I036, quoted at length in (I921) 30 Y YLE LAw Journal, 621. There the union officers "notified" various contractors and employers of labor that the plaintiff company was "unfair" and that union men would not work on materials bought from the plaintiff. This caused various contractors to cancel orders previously given to the plaintiff and accepted by it. The court said: "The fact that some of them violated their existing contracts cannot be deemed a wrong caused by the defendants. It was a wrong for which the contractors alone were responsible." In Cohen etc. Co. v. Bricklayers' Union (19I7) 92 Conn. 16I, 167, 101 Atl. 659, 66I, Wheeler, J., said: "The cessation of work was not intended to cause a breach of existing contracts, and the cancellation of some of its contracts by the plaintiff is, so far as we know, attributable to the plaintiff's act, rather than to the defendants' . . . . we can see no unlawfulness in their notice to contractors and employers of what would happen if nonunion men were employed on jobs on which they were engaged. The notice was the course of fair dealing. It did not take away the free choice from the contractor or owner;: it possessed him of the facts which might affect his decision." These two cases differ from the instant case in various details that may be regarded as of importance. In both cases the defendants indirectly threatened to strike; but in neither does it definitely appear that the defendants knew of the existing contracts. It is believed, however, that neither court, in its then existing state of mind, would have regarded such knowledge as a legally operative fact. 
made by $\mathrm{X}$ in person or by an agent who represents $\mathrm{X}$ and his associated manufacturers.

It may be admitted that judgment should go against the defendant in case he approached McLachlan with the purpose and intent of causing the latter to break his contract with the plaintiff. In the instant case no such purpose or intent was proved. Mere knowledge, however, on the part of the defendant, that compliance with his request would probably cause McLachlan to break his contract, is not enough to make the defendant guilty of a tort. The defendant's duty to the plaintiff is surely no greater than his duty to society, and it is well established that one is privileged to sell goods to another even though he knows that the buyer intends to make an illegal use of the goods. ${ }^{16}$ Thus it has been held that it is not illegal to sell liquors to A merely because the seller "knows" that A intends to use them in breach of the criminal law; the sale to A not being in itself forbidden, it becomes unlawful only when made by the seller "with a view" to its subsequent illegal use by $\mathrm{A} .{ }^{17}$

It seems, therefore, that the defendant was guilty of no breach of the plaintiff's "property right in the contract." He had "just cause" for his statement to McLachlan, such cause consisting in his desire for economic advantages. Such cause may cease to be just and sufficient if accompanied by a conscious purpose and intent to induce a breach of contract. The defendant may have had such a purpose and may have covertly threatened a strike $e^{18}$ in order to attain this end; but judgment should not go against him when there has been no finding by the court that either fact existed.

A. L. C.

In People v. Gitlow (1922) 234 N. Y. ${ }^{2} 2$, I36 N. E. $3^{\text {I7 }}$, the New York Court of Appeals had occasion to interpret and apply the state statute making "advocacy of criminal anarchy" a felony. The statute defines "criminal anarchy" as "the doctrine that organized government should be overthrown by force or violence, or by assassination ....., or by any unlawful means." The defendant, a "left wing socialist," plainly advocated in print the overthrow of the existing government in this country by the mass strike and the establishment in its place by revolution of a dictatorship of the proletariat. The court wasted no time on the question of the constitutionality of the statute; and the majority

\footnotetext{
${ }^{16}$ This may not be true in case the illegal use is a crime of great magnitude, such as murder; but it is true of misdemeanors, and it should be true in cases of mere torts and breaches of contract.

${ }^{17}$ Graves v. Jolmson (I892) I56 Mass. 2II, 30 N. E. 8I8, (I90I) 179 Mass. 53, 60 N. E. 383 .

${ }^{18}$ That a "threat" to strike may be unlawful even though the strike itself would not be, see Smith, Crucial Issues in Labor Litigation (Igo7) 20 Harv. L. REv. 253,273 .
} 